\title{
Relation between milk consumption and ethnicity, economic status and parent's education level among primary school children in the north of Iran
}

Gholamreza Veghari ${ }^{1}$

Sri Lanka Journal of Child Health, 2013; 42(1): 33-37

\section{Introduction}

Milk is the best source of nine essential nutrients that children need for good health, including calcium, protein, potassium, phosphorous, vitamins A, D and B12, riboflavin and niacin ${ }^{1}$. At around 12 years of age children whose mothers received calcium supplementation during pregnancy had a significant reduction in dental caries ${ }^{2}$. Garry ${ }^{3}$ reported that only $10 \%$ of girls aged $9-17$ year ingest calcium according to recommended daily allowances.

Milk consumption decreased in students when they are exposed to sweet beverages and other low health foods ${ }^{4}$. Maternal knowledge and training of them about milk benefits can be lead to more consumption by the students ${ }^{5}$. Some milk consumption related factors are age, parents' education, race, income, gender, personality and environment ${ }^{5-9}$.

Of $1,600,000$ populations in the Golestan province (north of Iran), $43.9 \%$ and $56.1 \%$ are living in urban and rural areas respectively. Agriculture is the main job in rural areas and different ethnic groups such as Fars-native, Turkman and Sisstani are living in this region $^{10}$.

The main aim of this study was to evaluate milk consumption status and interest in milk among northern Iranian primary school children in 2010.

\section{Method}

This was a descriptive and cross-sectional study which was carried out on 7,430 primary school children (3,935 boys, 3495 girls) from 112 schools of urban and rural areas in northern Iran. The schools and students were chosen by cluster and stratified sampling. For all children a questionnaire was filled which contained questions on the milk consumption rate, interest rate in milk and socio-economic condition of school children. The different items studied in this investigation were: gender, ethnicity and parents' education.

The ethnic groups in this study were divided into four: 1) Fars-native: The natural inhabitants of this province, which they are recognized with same name on 25 May 2012)
(Received on 10 April 2012: Accepted after revision

${ }^{1}$ Assistant Professor of Nutrition and Faculty
Member, Golestan University of Medical Sciences,

${ }^{1}$ Assistant Professor of Nutrition and Faculty
Member, Golestan University of Medical Sciences, Gorgan, Iran

(Key word: Milk; school; children; race; Iran)

\begin{abstract}
Method: This was a descriptive cross-sectional study
performed in 7430 students ( 3935 male) from 112
schools in urban and rural areas. The schools and
students were chosen by cluster and stratified
sampling. Data was collected for all samples through
interview.
Results: Milk consumption was present in $62.7 \%$ of
students (female $60.7 \%$, male $64.5 \%$ and in
Turkman ethnic groups ( $66.0 \%)$ was significantly
more than in other ethnic groups such as Fars-native
(61.4\%) and Sisstanish ethnic group (58.2\%)
(P=0.001). The odds ratio estimate for milk
consumption was 1.85 [95\% CI: $1.59,2.16]$ for good
economic group compared to poor economic group;
1.17 [95\% CI:1.05-1.31] for students whose mothers
had 1-12 years schooling compare to students whose
mother were illiterate; 1.31 [95\% CI:1.09-1.08] for
students whose father were college educated
compared to students whose fathers were illiterate.
The odds ratio estimate for interest in milk was 0.84
[95\% CI: 0.73, 0.99] for good economic group
compared to poor economic group; 0.88 [95\% CI:
$0.79-0.99$ ] for students whose mothers had $1-12$ years
schooling compared to students whose mothers were
illiterate.
Conclusions: Milk consumption was shown among than in girls, in urban than in rural areas and in Turkman ethnic groups $(66 \%)$ than in other ethnic groups. High interest in milk was shown among 66\% students. milk consumption status and interest in milk among
\end{abstract}


in the society 2) Turkman: The inter marriage of this ethnic group with other ethnic groups was rare; therefore this ethnic group can be recognized as a pure race. 3) Sisstanish ethnic group: This ethnic group immigrated from Sisstan and Bluchestan province from the east of Iran far earlier. 4) Others.

Economic status: The economic ranking of the families in this study was assessed on the basis of 12 items and principles. On the basis of those 12 items the children's family was divided as 1) good, 2) intermediate and 3) poor.

Parents' educational level: The educational level was divided into 3 groups: 1) Illiterate: People who could neither read nor write. 2) People having 1-12 year education at schools 3) People with university education.
Milk consumption: Milk or its exchanges that is consumed at breakfast by student.

SPSS 16.0 software was used for statistical data analysis. Chi-2 test and logistic regression were used for analysis and P. value under 0.05 was considered significant.

This protocol was approved by the ethics panel of Golestan University of Medical Sciences and consent document has been kept by subject. Unwilling subjects were excluded from this study

\section{Results}

Milk consumption and the interest of school children in it are presented in table 1.

Table 1: Comparison of interest in milk and milk consumption based on gender, location area and ethnicity in primary school children.

\begin{tabular}{|c|c|c|c|c|c|c|c|c|c|}
\hline \multirow{2}{*}{\multicolumn{2}{|c|}{ Characters }} & \multirow{3}{*}{$\begin{array}{l}\mathbf{N} \\
3935\end{array}$} & \multicolumn{3}{|c|}{ Interest in milk } & \multirow[t]{2}{*}{ P.value * } & \multicolumn{2}{|c|}{ Milk consumption } & \multirow[t]{2}{*}{ P.value } \\
\hline & & & Low & Moderate & High & & No & Yes & \\
\hline \multirow[t]{2}{*}{ Gender } & Male & & $\begin{array}{c}474 \\
(12.0)\end{array}$ & $\begin{array}{c}819 \\
(20.8)\end{array}$ & $\begin{array}{l}2642 \\
(67.1)\end{array}$ & \multirow[b]{2}{*}{0.004} & $\begin{array}{c}1397 \\
(35.5)\end{array}$ & $\begin{array}{c}2538 \\
(64.5)\end{array}$ & \multirow{2}{*}{0.001} \\
\hline & Female & 3495 & $\begin{array}{c}557 \\
(15.9)\end{array}$ & $\begin{array}{c}701 \\
(20.1)\end{array}$ & $\begin{array}{c}2237 \\
(64.0)\end{array}$ & & $\begin{array}{c}1373 \\
(39.3)\end{array}$ & $\begin{array}{l}2123 \\
(60.7)\end{array}$ & \\
\hline \multirow[t]{2}{*}{$\begin{array}{c}\text { Location } \\
\text { area }\end{array}$} & Urban & 3656 & $\begin{array}{c}469 \\
(12.8)\end{array}$ & $\begin{array}{c}814 \\
(22.3)\end{array}$ & $\begin{array}{l}2373 \\
(64.9)\end{array}$ & \multirow{2}{*}{0.174} & $\begin{array}{c}1276 \\
(34.9)\end{array}$ & $\begin{array}{c}2380 \\
(65.1)\end{array}$ & \multirow{2}{*}{0.001} \\
\hline & Rural & 3774 & $\begin{array}{c}562 \\
(14.9) \\
\end{array}$ & $\begin{array}{c}706 \\
(18.7) \\
\end{array}$ & $\begin{array}{c}2506 \\
(66.4) \\
\end{array}$ & & $\begin{array}{c}1493 \\
(39.6) \\
\end{array}$ & $\begin{array}{c}2281 \\
(60.4) \\
\end{array}$ & \\
\hline \multirow[t]{4}{*}{$\begin{array}{c}\text { Ethnicity } \\
* *, * * *\end{array}$} & Fars-native & 2895 & $\begin{array}{c}397 \\
(13.7)\end{array}$ & $\begin{array}{c}658 \\
(22.7) \\
\end{array}$ & $\begin{array}{l}1840 \\
(63.6)\end{array}$ & \multirow{4}{*}{0.001} & $\begin{array}{c}1118 \\
(38.6)\end{array}$ & $\begin{array}{c}1777 \\
(61.4)\end{array}$ & \multirow{4}{*}{0.001} \\
\hline & Turkman & 2845 & $\begin{array}{c}362 \\
(12.7) \\
\end{array}$ & $\begin{array}{c}538 \\
(18.9) \\
\end{array}$ & $\begin{array}{c}1945 \\
(68.4) \\
\end{array}$ & & $\begin{array}{c}967 \\
(34.0) \\
\end{array}$ & $\begin{array}{c}1878 \\
(66.0) \\
\end{array}$ & \\
\hline & Sisstani & 1333 & $\begin{array}{c}225 \\
(16.9)\end{array}$ & $\begin{array}{c}252 \\
(18.9)\end{array}$ & $\begin{array}{c}856 \\
(64.2) \\
\end{array}$ & & $\begin{array}{c}557 \\
(41.8) \\
\end{array}$ & $\begin{array}{c}776 \\
(58.2) \\
\end{array}$ & \\
\hline & Others & 357 & $\begin{array}{c}47 \\
(13.2) \\
\end{array}$ & $\begin{array}{c}72 \\
(20.2) \\
\end{array}$ & $\begin{array}{c}238 \\
(66.6) \\
\end{array}$ & & $\begin{array}{c}127 \\
(35.6) \\
\end{array}$ & $\begin{array}{c}230 \\
(64.4) \\
\end{array}$ & \\
\hline \multicolumn{2}{|c|}{ Total } & 7430 & $\begin{array}{c}1031 \\
(13.8)\end{array}$ & $\begin{array}{l}1520 \\
(20.5)\end{array}$ & $\begin{array}{r}4879 \\
(65.7)\end{array}$ & & $\begin{array}{r}2769 \\
(37.3)\end{array}$ & $\begin{array}{l}4661 \\
(62.7)\end{array}$ & \\
\hline
\end{tabular}

${ }^{*}$ Chi-2 test between groups based on high interest in milk. ${ }^{* *}$ Chi-2 test based on high interest in milk obtained between Fars-native and Turkman $(P=0.001)$, between Turkman and Sisstani $(P=0.007)$ and between Fars-native and Sisstani $(P=0.050)$. ${ }^{* * *}$ Chi-2 test based on milk consumption obtained between Fars-native and Turkman $(P=0.004)$, between Turkman and Sisstani $(P=0.001)$ and between Fars-native and Sisstani $(P=0.047)$.

The interest in milk rated as high, medium and low were $65.7 \%, 20.5 \%$ and $13.9 \%$, respectively and it was significantly more in boys than girls $(\mathrm{P}=0.004)$. High interest in milk in Turkman ethnic group was significantly more than in Fars-native $(\mathrm{P}=0.007)$ and more than in Sisstanish ethnic group $(\mathrm{P}=0.001)$. As a whole, $62.7 \%$ of students consumed milk at breakfast and this was significantly more in boys more than girls $(\mathrm{P}=0.001)$ and significantly more in urban than rural areas $(\mathrm{P}=0.001)$. Milk consumption rate was significantly more in Turkman ethnic group than in Fars-native $(\mathrm{P}=0.004)$ and significantly more than in Sisstanish ethnic group $(\mathrm{P}=0.001)$. Further, it was significantly more in Fars-native than in Sisstanish ethnic group $(\mathrm{P}=0.047)$.

Multiple logistic regression was used to identify variables that contribute to consumption of milk at 
breakfast. The odds ratio estimate was 1.53 [95\% CI: $1.34,1.74]$ for moderate economic group compared to poor economic group; 1.85 [95\% CI: $1.59,2.16]$ for good economic group compared to poor economic group; 1.17 [95\% CI:1.05-1.31] for students whose mother had 1-12 years schooling compared to students whose mother was illiterate; 1.31 [95\%
CI:1.09-1.08] for students whose father was college educated compared to students whose father was illiterate. Differences were not significant in students whose mothers were college educated and fathers with 1-12 years schooling compared to illiterate groups (Table2).

Table 2: Odds ratio for milk consumption among primary school children in the north of Iran

\begin{tabular}{|l|c|c|c|}
\hline \multicolumn{1}{|c|}{ Risk factor } & Level & OR (95\% CI) & P. value \\
\hline \multirow{3}{*}{ Economic status } & Poor & (Ref) & \\
\cline { 2 - 4 } & Moderate & $1.530(1.343-1.743)$ & 0.001 \\
\cline { 2 - 4 } & Good & $1.850(1.587-2.156)$ & 0.001 \\
\hline \multirow{3}{*}{ Maternal Educational level } & Illiterate & $1.173(1.051-1.308)$ & 0.0001 \\
\cline { 2 - 4 } & $1-12$ years schooling & $1.116(0.915-1.361)$ & 0.279 \\
\cline { 2 - 4 } & College & $($ Ref $)$ & 0.074 \\
\hline \multirow{3}{*}{ Father Educational level } & Illiterate & $1.141(0.981-1.318)$ & 0.004 \\
\cline { 2 - 4 } & $1-12$ years schooling & $1.313(1.089-1.584)$ & \\
\cline { 2 - 4 } & College & & \\
\hline
\end{tabular}

Multiple logistic regression was used to identify variables that contributed to interest in milk consumption. The odds ratio estimate was $1.25[95 \%$ CI: $1.11,1.40]$ for moderate economic group compared to poor economic group; 0.84 [95\% CI: $0.73,0.99]$ for good economic group compared to poor economic group; 0.88 [95\% CI:0.79-0.99] for students whose mothers had 1-12 years schooling compared to students whose mother were illiterate; 0.80 [95\% CI:0.66-0.98] for students whose mothers were college educated compared to students whose mothers were illiterate; 0.80 [95\% CI:0.66-0.94] for students whose fathers were college educated compared to students whose fathers were illiterate. Difference was not significant between 1-12 years schooling fathers and illiterate fathers (Table 3 )

Table 3: Odds ratio for interest in milk among primary school children in the north of Iran

\begin{tabular}{|c|c|c|c|}
\hline Risk factor & Level & OR (95\% CI) & P. value \\
\hline \multirow{3}{*}{ Economic status } & Poor & (Ref) & \\
\hline & Moderate & $1.248(1.111-1.401)$ & 0.0001 \\
\hline & Good & $0.853(0.732-0.994)$ & 0.041 \\
\hline \multirow{3}{*}{ Maternal Educational level } & Illiterate & (Ref) & \\
\hline & $1-12$ years schooling & $0.882(0.787-0.987)$ & 0.029 \\
\hline & College & $0.804(0.658-0.983)$ & 0.033 \\
\hline \multirow{3}{*}{ Father Educational level } & Illiterate & (Ref) & \\
\hline & 1-12 years schooling & $0.876(0.753-1.020)$ & 0.88 \\
\hline & College & $0.795(0.657-0.963)$ & 0.019 \\
\hline
\end{tabular}

\section{Discussion}

In Tehran (centre of Iran) ${ }^{11}$ the rate of milk consumption at breakfast was $42 \%$. In Sari (north of Iran) ${ }^{12}$ and Birjand (Southeast of Iran) ${ }^{7}$ the lack of milk consumption at breakfast was $5.5 \%$ and $8.2 \%$ of school children, respectively. In Syria ${ }^{13}$ more than $35 \%$ of students consumed milk at least once a week and in Warshow ${ }^{14}$ the proportion of milk in breakfast meal was very low. The consumption of milk in the north of Iran and in the other part of Iran is similar.
In the present study, milk consumption in students was associated with high economic families or with high educated parents whereas interest in milk in students with illiterate parents and in families with moderate economic status was more than in other groups.

Mother's education more than fathers' education has effects on children's nutritional status ${ }^{12,15}$ and income has a positive relationship with milk consumption ${ }^{16}$. Association between family income and their children's nutritional status has been shown in a study in Bangladesh ${ }^{5}$. A barrier to milk consumption 
that was more common was limited expectation within families for drinking milk ${ }^{3}$. As in other studies, we found the important role of family social level on the students' milk consumption.

Similar to the other studies ${ }^{7,16}$ we found the milk consumption in boys more than girls. Beverage drinking is strongly related to gender $^{8}$ and psychological factors may reduce milk consumption in girls.

Veghari ${ }^{17,18}$ in northern Iran has shown the difference in nutritional status among three ethnic groups with a better situation in Turkman ethnic group.

Evans ${ }^{16}$ found low differences of milk consumption between African-American and American ethnic groups and Soh $^{19}$ believed that psycho-pathologic factors more than ethnicity related to interest in foods and $\operatorname{Gordan}^{20}$ investigated the association between nutritional status and socio-economic factors in white and black people. Reaction to milk in Hispanic and white girls in USA was different ${ }^{3}$.

In our study, increasing milk consumption in urban area is in line with other studies ${ }^{16}$. These studies reported that booming of economic status and urbanization resulted in improvement of nutritional status and quality of food intake. Lack of awareness and education about food behaviour are the barriers of extension of good habits in students ${ }^{21}$.

\section{Conclusions}

- Milk consumption was present among $63 \%$ of students and was significantly more in boys than in girls, in urban than in rural areas and in Turkman ethnic groups than in other ethnic groups.

- High interest in milk was shown by $66 \%$ of students and was significantly more in boys than in girls and in Turkman ethnic groups (66\%) than in other ethnic groups..

\section{Acknowledgments}

The authors would like to thank the medical and administrative staff in the Primary Health Care Centers of Golestan University of Medical Sciences for their valuable assistance during the field work. Also, the Research Deputy of the University is thanked for supporting this project financially.

\section{References}

1. Mahan L, Escott-Stump S, editors. Krause's food and Nutrition therapy. $12^{\text {th }}$ ed, London: Saunders; 2008.

2. Bergel E, Gibbons L, Rasines MG, Luetich A, Belizán JM. Maternal calcium supplementation during pregnancy and dental caries of children at 12 years of age: follow-up of a randomized controlled trial. Acta Obstetricia et Gynecologica Scandinavica 2010; 89(11):1396-402. http://dx.doi.org/10.3109/00016349.2010.51822 $\underline{8}$

3. Garry A, Carol JB, Margaret AB, Christine B, Kathe G. Perspectives on intake of calcium rich foods among Asian, Hispanic, and white preadolescent and adolescent females. Journal of Nutrition Education 2002; 34: 242-5. http://dx.doi.org/10.1016/S1499-4046(06)60102$\underline{4}$

4. Cullen KW, Zakeri I. Fruits, vegetables, milk, and sweetened beverages consumption and access to à la carte/snack bar meals at school. American Journal of Public Health 2004; 94(3): 463-7. http://dx.doi.org/10.2105/AJPH.94.3.463

5. Ahmed F, Zareen M, Khan MR, Banu CP, Haq MN, Jackson AA. Dietary pattern, nutrient intake and growth of adolescent school girls in urban Bangladesh. Public Health Nutrition 1998; 1(2):83-92. http://dx.doi.org/10.1079/PHN19980014

6. Hendijani B, Ab Karim R. Factors affecting milk consumption among school children in urban and rural areas of Selangor, Malaysia. International Food Research Journal 2010; 17: 651-60.

7. Kaheni F, Kaheni S, Sharifzadeh GR, Nasiri Foorg A, Avan M. Consumption amount of milk and dairy products in school children of 6-11 year olds in Birjand during 2007. Journal of Birjand University of Medical Sciences 2009; 16(2): 61-67.

8. Forshee RA, Storey ML. Total beverage consumption and beverage choices among children and adolescents. Journal of Food Sciences and Nutrition 2003; 54(4): 297-307. 
9. Novotny R, Acharya S, Grove JS, Vogt TM. Dairy intake is associated with lower body fat and soda intake with greater weight in adolescent girls. Journal of Nutrition 2004; 134(8): 1905-9.

10. Statistical Centre of Iran. Population and Housing Census. Available from:

http://www.sci.org.ir

11. Soheili Azad AA, Nourjah N, Aalamdar E. Surveying the food intake of primary school students in Tehran. Journal of the Shaheed Beheshti University of Medical Sciences and Health Services 2005; 29(2):165-8.

12. Vahedi H, Pourabdollahi P, Biglarian A. Study of awareness towards and the pattern of milk consumption in 7-12 year old elementary school students in the city of Sari and their mothers (2005-2006). Journal of Mazandaran University of Medical Sciences 2007; 17(59): 94-102.

13. Bashour HN. Survey of dietary habits of inschool adolescents in Damascus, Syrian Arab Republic. Eastern Mediterranean Health Journal 2004; 10(6):853-62.

14. Hamułka J, Gronowska-Senger A, Witkowska K. Frequency of intake and energy value of breakfast for students from selected primary schools in Warsaw. Rocz Panstw Zakl Hig. 2000; 51(3):279-90.

15. Janevic T, Petrovic O, Bjelic I, Kubera A. Risk factors for childhood malnutrition in Roma settlements in Serbia. BMC Public Health 2010; 10:509.

http://dx.doi.org/10.1186/1471-2458-10-509
16. Evans AE, Springer AE, Evans MH, Ranjit N, Hoelscher DM. A descriptive study of beverage consumption among an ethnically diverse sample of public school students in Texas. Journal of the American College of Nutrition 2010; 29(4):38796.

17. Veghari G. Comparative study of breast-feeding state among Fars (native),Turkman, and Sistani Ethnic Group of Rural Areas in Gorgan District. Pakistan Journal of Nutrition 2006; 5(6): 594-6. http://dx.doi.org/10.3923/pjn.2006.594.596

18. Veghari G - Golalipour MJ. The comparison of nutritional status between Turkman and nonTutkman ethnic groups in North of Iran. Journal of Applied Sciences 2006; 7(18):2635-40.

19. Soh NL, Touyz S, Dobbins TA, Surgenor LJ, Clarke S, Kohn MR, et al. Restraint and eating concern in North European and East Asian women with and without eating disorders in Australia and Singapore. Australia and New Zealand Journal of Psychiatry 2007; 41(6):53645.

http://dx.doi.org/10.1080/00048670701332318

20. Gordon-Larsen P, Adair LS, Popkin BM. The relationship of ethnicity, socioeconomic factors, and overweight in US adolescents. Obesity Research 2003; 11(1):121-9.

http://dx.doi.org/10.1038/oby.2003.20

21. Berg MC, Jonsson I, Conner MT, Lissner L. Relation between breakfast food choices and knowledge of dietary fat and fiber among Swedish schoolchildren. Journal of Adolescent Health 2002; 31(2):199-207. http://dx.doi.org/10.1016/S1054139X(02)00391$\underline{9}$ 